\title{
PENGARUH INTELLECTUAL CAPITAL TERHADAP RETURN ON ASSET PADA BANK UMUM SYARIAH DI
} INDONESIA PERIODE Q1.2013 - Q4.2014 1)

\author{
Umi Muhanik \\ Mahasiswa Program Studi S1 Ekonomi Islam-Fakultas Ekonomi dan Bisnis-Universitas Airlangga \\ Email: umi.muhanik-12@feb.unair.ac.id
}

Dina Fitrisia Septiarini

Departemen Ekonomi Islam Fakultas Ekonomi dan Bisnis Universitas Airlangga

Email: dina.fitrisia@feb.unair.ac.id

\begin{abstract}
:
This study aimed to analyze the effect of Intellectual Capital to Return on Assets (ROA) sharia banks Q1.2013 - Q4.2014 period. The method used is quantitative method with jenuh sampling technique. This study uses 11 Islamic banks and the technique used is the panel data regression. The process of calculating this study using Eviews 8.0 program. Independent variables used Intellectual Capital is VACA, VAHU, STVA and dependent variables use Return on Assets (ROA). The data used is secondary data with the collected data quarterly financial report for the period Q1.2013-Q4.2014.

Hypothesis testing is done using simultaneous significance test (F test) and partial significance test (t test). Panel data analysis conducted showed that simultaneous VACA, VAHU, STVA significant effect on ROA while partial VACA no significant effect on ROA, VAHU significant effect on ROA, STVA no significant effect on ROA.
\end{abstract}

Keywords: Panel Data Analysis, VACA, VAHU, STVA, ROA

\section{PENDAHULUAN}

Peran ilmu pengetahuan tidak

kompetisi perusahaan dan keberadaan hanya sebagai faktor pendukung, namun berkembang pesat menjadi aspek penentu bagi kemajuan bisnis yang kompetitif. Peran Islam yaitu menjadikan aqidah Islam sebagai paradigma ilmu pengetahuan dimana paradigma ini harus dimiliki oleh setiap umat. Intelectual capital menjadi bagian penting dari perekonomian, karena semakin meningkatnya persaingan maka salah satu cara mengantisipasi dengan meningkatkan intellectual capital pada sebuah perusahaan.

Perusahaan dalam menyeleksi karyawan perbankan syariah harus mengutamakan yang mempunyali latar belakang ekonomi syariah. Sumber daya manusia menjadi faktor utama dalam sumber daya manusia dalam sebuah perusahaan memiliki posisi yang sangat penting.

Perbankan adalah lembaga kevangan yang usaha pokoknya kembali dana tersebut ke masyarakat dalam bentuk kredit serta memberikan jasa-jasa dalam lalu lintas pembayaran dan peradaran uang (Kuncoro, 2002:68).

Perkembangan perbankan syariah di Indonesia menjadi tolak ukur keberhasilan eksistensi ekonomi syariah dan Bank Muamalat sebagai bank syariah pertama yang telah lebih dahulu menerapkan system ini ditengah berkembangnya bank-bank konvensional. Lahirnya Undang-Undang No.21 1) Jurnal ini merupakan bagian dari skripsi yang ditulis oleh Umi Muhanik, NIM 041211431155 yang diuji pada 3 juni 2016. 
Muhanik, et al/Jurnal Ekonomi Syariah Teori dan Terapan Vol. 4 No. 1 Januari 2017: 1-13; PENGARUH INTELLECTUAL CAPITAL TERHADAP RETURN ON ASSET PADA BANK UMUM SYARIAH DI INDONESIA PERIODE Q1.2013 - Q4.2014

landasan operasi bagi bank syariah dengan adanya berbagai regulasi dan kebijakan pengembangan perbankan syariah maka dapat dilihat bahwa terjadi peningkatan pada industri perbankan syariah.

Industri perbankan syariah sebagai institusi bisnis yang berbasis nilai-nilai dan prinsip-prinsip syariah, kualifikasi dan kualitas Sumber Daya Manusia (SDM) jelas lebih di tuntut adanya keter-paduan antara kurikulum dasar tentang ekonomi syariah dengan keahlian atau keterampilan dalam industry perbankan. Penyebab utama kete-rbatasan SDM adalah kurangnya lulusan dengan latar belakang pendidikan Ekonomi Syariah (www.suarakarya.id).

Intellectual capital menarik untuk di teliti karena fenomena itu terjadi ketika intellectual capital berkembang terutama setelah munculnya PSAK No.19 (revisi 2000) tentang aktiva tidak berwujud (IAI, 2007).

Pulic (1998) dalam Ulum (2013) mengusulkan bahwa,

"Mengenai pengukuran secara tidak langsung terhadap Intellectual Capital dengan suatu ukuran untuk menilai efisiensi dari nilai tambah sebagai hasil dari kemampuan intelektual perusahaan, yaitu menggunakan Value Added Intellectual Coefficient (VAIC). Komponen utama dari VAIC dapat dilihat dari sumber daya perusahaan, yaitu physical capital (VACA-Valve Added Capital Employed), Human Capital (VAHU-Value Added Human Capital), dan Structural Capital (STVA-Structural Capital Valve Added). "
Penelitian yang telah dilakukan oleh Kuryanto dan Syafruddin (2008) yang meneliti pengaruh Modal Intelektual terhadap kinerja perusahaan yang terdaftar di Bursa Efek Indonesia tidak ada pengaruh positif antara IC sebuah perusahaan dan kinerjanya. Sedangkan Ulum (2008) yang berjudul pengaruh intellectual capital terhadap kinerja kevangan perbankan di indonesia. Hasil penelitian ini terdapat pengaruh positif intellectual capital terhadap kinerja perbankan.

Rumusan Masalah

1. Apakah Value Added Capital Employed (VACA) mempunyai pengaruh secara parsial terhadap Return On Asset (ROA) Bank Umum Syariah?

2. Apakah Value Added Human Capital (VAHU) mempunyai pengaruh secara parsial terhadap Return On Asset (ROA) Bank Umum Syariah?

3. Apakah Structural Capital Value Added (STVA) mempunyai pengaruh secara parsial terhadap Return On Asset (ROA) Bank Umum Syariah?

4. Apakah Value Added Capital Employed (VACA), Value Added Human Capital (VAHU), Structural Capital Value Added (STVA) mempunyai pengaruh secara simultan terhadap Return On Asset (ROA) Bank Umum Syariah?

Tujuan Penelitian

Berdasarkan rumusan masalah yang di ajukan dalam proposal, maka tujuan dari penelitian ini adalah untuk: 
1. Mengetahui pengaruh Value Added Capital Employed (VACA) terhadap Return On Asset (ROA) Bank Umum Syariah secara parsial.

2. Mengetahui pengaruh Value Added Human Capital (VAHU) terhadap Return On Asset (ROA) Bank Umum Syariah secara parsial.

3. Mengetahui pengaruh Structural Capital Value Added (STVA) terhadap Return On Asset (ROA) Bank Umum Syariah secara parsial.

4. Mengetahui pengaruh Value Added Capital Employed (VACA), Value Added Human Capital (VAHU), Structural Capital Value Added (STVA) terhadap Return On Asset Bank Umum Syariah secara simultan.

\section{LANDASAN PUSTAKA}

Resource Based Theory dipelopori oleh Penrose (1959) dalam Astuti (2004), mengemukakan bahwa,

"Sumber daya perusahaan adalah heterogen, tidak homogen, jasa produktif berasal dari sumber daya perusahaan yang memberikan karakter unik bagi tiap-tiap perusahaan."

Resource Based Theory (RBT) itu sendiri merupakan teori yang bertujuan untuk menganalisis dan menginterpretasikan sumber daya organisasi untuk memahami bagaimana organisasi tersebut mencapai suatu keunggulan kompetitif yang berkelanjutan (Madhani (2009) dalam Astuti (2004) .

Human capital theory dikembangkan oleh Becker (1964) yang mengemukakan bahwa investasi dalam pelatihan dan meningkatkan human capital adalah penting sebagai suatu investasi dari bentuk-bentuk modal lainya. Skill, pengalaman dan pengetahuan memiliki nilai ekonomi bagi organisasi karena hal tersebut memungkinkan untuk produktif dan dapat beradaptasi (Astuti, 2004).

Deegan (2004) dalam Ulum (2009:5) menyatakan bahwa

"Teori stakeholder menekankan akuntabilitas organisasi jauh melebihi kinerja keuangan atau ekonomi sederhana. Teori ini menyatakan bahwa organisasi akan memilih secara sukarela mengungkapkan informasi tentang kinerja lingkungan, sosial dan intelektual melebihi dan diatas permintaan wajibnya, untuk memenuhi ekspektasi sesungguhnya atau yang di akui oleh stakeholder." Intellectual capital menurut

Purnomosidhi (2006) di definisikan sebagai informasi dan pengetahuan yang di aplikasikan dalam pekerjaan untuk menciptakan nilai.

Stewart (1997) dalam Sangkala (2006) menjelaskan bahwa intellectual capital merupakan materi intelektual berupa informasi, pengetahuan, inovasi, intellectual, pengalaman, yang dapat dimanfaatkan dalam menghasilkan aset yang mempunyai nilai tambah dan memberikan keunggulan bersaing.

Meritum (2003) dalam Sangkala (2006:37) berpendapat bahwa intellectual capital merupakan kombinasi manusia, sumber daya perusahaan dan relasi dari suatu perusahaan yang menunjukan yang menunjukan bahwa nilai yang diciptakan melalui hubungan antara tiga kategori yaitu modal manusia, sructural dan relasi 
perusahaan. Hubungan yang baik antara ketiga kategori itu merupakan kunci dan sumber potensial untuk mendapatkan keunggulan kompetitif (sustainable competitive advantage) (Tayes et al.2002; Hayton 2005 dalam Purnomosidhi, 2006).

Hubungan intellectual capital dengan kinerja keuangan perusahaan seperti yang penelitian dilakukan oleh chen et al (2005) dan Ulum (2008) bahwa intellectual capital berhubungan positif dengan kinerja keuangan termasuk profitabilitas (Ulum, 2009:102). Intellectual Capital secara simultan berpengaruh terhadap kinerja keuangan (ROA), Human Capital tidak berpengaruh terhadap ROA, Structural Capital berpengaruh terhadap ROA, Capital Employed tidak berpengaruh terhadap ROA (Satiti, 2013).

\section{Hipotesis dan Model Analisis}

Penelitian ini menganalisis tentang pengaruh Intellectual capital terhadap Return on Asset (ROA) pada Bank Umum Syariah pada periode Q1.2013-Q4.2014 Variabel yang digunakan dalam penelitian ini adalah Valve Added Capital Employed (VACA), Value Added Human Capital (VAHU), Structural Capital Value Added (STVA). Berdasarkan tujuan penelitian ini maka hipotesis yang digunakan adalah:

$\mathrm{H}_{1} \quad$ :Value Added Capital Employed (VACA), Value Added Human Capital (VAHU), Structural Capital Value Added (STVA) mempunyai pengaruh secara simultan terhadap Return on Asset (ROA) pada Bank Umum Syariah.
$\mathrm{H}_{2}$ :Value Added Capital Employed (VACA) mempunyai pengaruh secara parsial terhadap Return on Asset (ROA) pada Bank Umum Syariah.

$\mathrm{H}_{3}$ :Value Added Human Capital (VAHU) mempunyai pengaruh secara parsial terhadap Return on Asset (ROA) pada Bank Umum Syariah.

$\mathrm{H}_{4} \quad$ Structural Capital Value Added (STVA) mempunyai pengaruh secara parsial terhadap Return on Asset (ROA) pada Bank Umum Syariah.

Dan model analisis dari penelitian ini adalah:

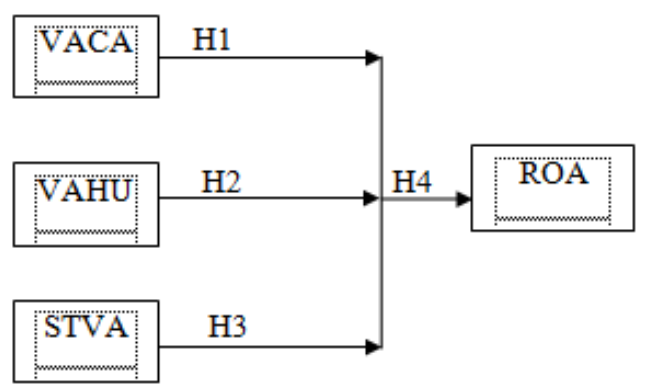

Sumber : Data diolah

Gambar 1.

Model Analisis

\section{METODE PENELITIAN}

Pendekatan dalam penelitian ini adalah pendekatan kuantitatif. Variabel eksogen (variabel independen) yang digunakan dalam penelitian ini adalah Intellectual capital yang di kembangkan oleh Pulic dengan menggunakan metode Value Added Intellectual Coefficient (VAIC), antara lain: a). Valve Added Capital Employed atau VACA $\left.\left(\mathrm{X}_{1}\right), \mathrm{b}\right)$. Value Added Human Capital atau VAHU 
$\left(\mathrm{X}_{2}\right)$, dan C). Structural Capital Value Added atau STVA $\left(\mathrm{X}_{3}\right)$. Variabel endogen merupakan variabel yang dipengaruhi atau yang menjadi akibat, karena adanya variabel eksogen (Sugiyono, 2011:39). Variabel endogen dalam penelitian ini adalah Return On Asset (ROA).

Populasi dalam penelitian ini adalah seluruh Bank Umum Syariah yang ada di Indonesia yang memenuhi kriteria dalam penelitian. Teknik pengambilan sample yang digunakan dalam penelitian ini adalah sampling jenuh yang merupakan teknik penelitian yang membuat generalisasi dengan kesalahan yang sangat kecil.

. Sampel yang di dapat selama periode Q1.2013-Q4.2014 berdasarkan kategori diatas sejumlah 11 Bank Umum Syariah (BUS) di Indonesia diantaranya: (1) Bank BRI Syariah, (2) Bank BCA Syariah, (3) Bank BJB Syariah, (4) Bank BNI Syariah, (5) Bank Mandiri Syariah, (6)Bank Bukopin Syariah, (7) Maybank Syariah, (8) Bank Mega Syariah, (9) Bank Muamalat Indonesia, (10) Bank Panin Syariah, (11) Bank Victoria Syariah.

\section{Definisi Operasional}

1. Return On Asset (ROA)

$$
\text { Menurut Kasmir (2014:202) ROA }
$$
merupakan suatu ukuran keberhasilan manajemen dalam mengelola perusahaan. Return On Asset (ROA) merupakan rasio profitabilitas perusahaan yang mengukur kemampuan bank dalam memperoleh laba dan efisiensi secara keseluruhan. Jenis data Return On Asset (ROA) yang digunakan merupakan data rasio. Return On Asset (ROA) dapat dihasilkan melalui rumus dalam Kasmir (2014:202)

$$
R O A=\frac{\text { Earning After Tax }}{\text { Total Asset }}
$$

Penelitian ini menggunakan data laporan keuangan triwulanan pada perusahaan Bank Umum Syariah pada periode tahun Q1.2013-Q4.2014.

a. Value Added Capital Employed

(VACA) dalam Ulum (2009:87) merupakan indikator untuk VA yang diciptakan oleh satu unit dari physical capital. Value Added Capital Employed (VACA) merupakan perbandingan Value Added (VA) dengan ekuitas perusahaan atau Capital Employed (CE), rasio ini menunjukan kontribusi yang di buat oleh setiap unit dari Capital Employed (CE) terhadap value added organisasi. Value added (VA) merupakan indikator yang paling objektif yang di gunakan untuk menilai keberhasilan sebuah perusahaan dan dapat menunjukan kemampuannya dalam menciptakan nilai (value creation) dengan cara :

$V A=$ OUT $-I N$

Value Added Capital Employed (VACA) sendiri dapat dihitung dengan menggunakan rumus dalam Ulum (2009:87) sebagai berikut:

$$
V A C A=\frac{V A}{C E}
$$

Dimana, Value Added (VA) = Selisih antara output dan input. 
Capital Employed $(\mathrm{CE})=$ Dana yang tersedia (total ekuitas)

2. Value Added Human Capital (VAHU),

Rasio ini menunjukan berapa banyak Value Added (VA) dapat dihasilkan dengan dana yang di keluarkan untuk tenaga kerja. Rasio ini juga menunjukan bahwa kontribusi yang di buat oleh setiap rupiah yang di investasikan dalam Human Capital terhadap value added organisasi. Value Added Human Capital (VAHU) dapat di hasilkan melalui rumus dalam Ulum (2009:89).

$$
V A H U=\frac{\mathrm{VA}}{\mathrm{HC}}
$$

Dimana, Value Added (VA) = Selisih antara output dan input Human capital $(\mathrm{HC})=$ Beban karyawan

4. Structure Capital Value Added (STVA)

Rasio ini di gunakan untk mengukur jumlah Structural Capital (SC) yang di butuhkan untuk menghasilkan 1 rupiah dari Value Added (VA) dan merupakan indikasi bagaimana keberhasilan Structural Capital (SC) dalam penciptaan nilai. Structure Capital Value Added (STVA) dapat di hasilkan melalui rumus dalam Ulum (2009:89).

$$
S T V A=\frac{S C}{V A}
$$

Dimana, Value Added (VA) = Selisih antara output dan input

Structural Capital (SC) = VA- HC

\begin{tabular}{lll}
\multicolumn{1}{c}{ Value Added } & \multicolumn{2}{c}{ Intellectual } \\
Coefficient & (VAIC ${ }^{\mathrm{TM}}$ ) & rasio ini \\
mengidentifikasikan & kemampuan
\end{tabular}

intellectual capital sebuah perusahaan yang juga dapat di anggap sebagai BPI (Business Performance Indicator). VAIC ${ }^{\mathrm{TM}}$ merupakan penjumlahan dari tiga koefisien diatas yaitu VACA, VAHU, dan STVA.

VAICTM $=$ VACA + VAHU +
STVA..........(3.6)

\section{Teknik Analisis}

Teknik yang digunakan dalam penelitian ini adalah regresi data panel. Proses perhitungan dalam penelitian ini menggunakan program Eviews versi 8. Teknik analisis data panel dalam penelitian ini memanfaatkan data yang didapatkan dari penggabungan antara data cross section (beberapa BUS tertentu) dengan data time series (lingkup waktu selama beberapa tahun tertentu) atau di sebut dengan data panel.

Estimasi model regresi panel, terdapat 3 pendekatan yang biasa digunakan yaitu Pool least square (PLS), Fixed Effects (FE), Random Effects (RE) (Ajija dkk, 201 1:57).

1. Pool Least Square (PLS)

Common Effects Model (CEM) merupakan pendekatan data panel yang paling sederhana. Mo-del ini hanya mengkombinasikan data time series dan cross section dalam bentuk pool.

$$
\mathrm{Y}_{\mathrm{it}}=\beta_{1}+\beta_{2}+\beta_{3} \mathrm{X}_{3 \mathrm{it}}+\beta_{3} \mathrm{X}_{3}+\ldots+\beta_{\mathrm{n}} \mathrm{X}_{\mathrm{nit}}+\mu_{\mathrm{it}}
$$

2. Fixed Effects Model (FEM)

Fixed Effects Model (FEM) mengansumsikan bahwa terdapat efek yang berbeda antar individu. Pengertian fixed effects ini didasarkan adanya 
perbedaan intersep antara perusahaan namun intersepnya sama antar waktu.

$$
\mathrm{Y}_{\mathrm{it}}=\alpha_{1}+\alpha_{2} \mathrm{D}_{2}+\ldots+\alpha_{\mathrm{n}} \mathrm{D}_{\mathrm{n}}+\beta_{2} \mathrm{X}_{2 \mathrm{it}}+\ldots+\beta_{\mathrm{n}} \mathrm{X}_{\mathrm{nit}}+\mu_{\mathrm{it}}
$$

3. Random Effects Model (Error

\section{Component Model)}

Random Effects Model (REM) ini menggunakan variabel gangguan (error terms). Model ini mengestimasi data panel dimana variabel gangguan mungkin saling ber-hubungan antar waktu dan antar individu.

$$
Y_{i t}=\alpha+\beta_{1} X_{1 i t}+\varepsilon_{i t} ; \varepsilon_{i t}=U_{i}+V_{t}+W_{i t}
$$

Langkah-langkah yang dilakukan dalam mendapatkan model yang tepat adalah pertama dilakukan uji Chow pada hasil estimasi FEM, setelah terbukti ada efek individu maka dilakukan uji hausman untuk menentukan antara FEM dan REM.

\section{Chow Test (Uji chow)}

Uji chow digunakan untuk memilih salah satu model pada regresi data panel, yaitu antara model efek tetap (fixed effect model) dengan model koefisien tetap (common effect model). Dalam pengujian ini dilakukan hipotesa sebagai berikut

$\mathrm{H}_{0}: \alpha 1=\alpha 2=\ldots=\alpha \mathrm{N}=\alpha$ (Common Effect Model)

$H_{1}$ : sekurang-kurangnya ada satu intersep ai yang berbeda (Fixed Effect Model)

Dasar penolakan terhadap Ho adalah dengan menggunakan F-statistik seperti berikut (Baltagi, 2005: 15):

Chow $=\frac{R S S_{1}-R S S_{2} /(N-1)}{R S S_{2} /(N T-N-K)}$.

Dengan :
RSS1 = Residual sum of square hasil pendugaan model common effect RSS2 = Residual sum of square hasil pendugaan model fixed effect $N=$ jumlah data cross section $\mathrm{T}=$ jumlah data time series $\mathrm{K}=$ jumlah variabel bebas

Statistik Chow test mengikuti

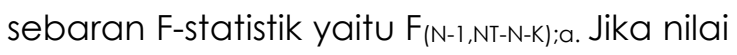
Chow statistik lebih besar dari F-tabel, maka menolak $\mathrm{H}_{0}$ dan sebaliknya (ajija dkk, 2011:58)

2. Hausman Test (Uji Hausman)

Uji hausman digunakan untuk membandingkan Fixed Effect Model (FEM) dengan Random Effect Model (REM). Uji hausman berdasar pada Fixed Effect Model (FEM) yang mengandung suatu unsur trade off yaitu hilangnya unsur derajat bebas dengan memasukan variabel dummy dan Random Effect Model (REM) yang harus memperhatikan ketiadaan pelanggaran asumsi dari setiap komponen galat. Dalam pengujian ini dilakukan hipotesis sebagai berikut: $\mathrm{H}_{0}: \operatorname{corr}($ Xit,Uit) $=0$ (Model Random Effect) $\mathrm{H}_{1}: \operatorname{corr}$ (Xit,Uit) $\neq 0$ (Model Fixed Effect)

\section{Analisis Koefisien Determinasi $\left(\mathbf{R}^{2}\right)$}

Analisis koefisien determinasi $\left(R^{2}\right)$ dimaksudkan untuk mengetahui ketepatan yang paling baik dalam menganalisis regresi, dimana hal yang ditunjukan oleh besarnya koefisien determinasi $\left(R^{2}\right)$ antara 0 (nol) dan 1 (satu). Jika koefisien determinasi $\left(R^{2}\right) \quad 0$ (nol), berarti variabel independen sama sekali tidak berpengaruh terhadap variabel dependen. Dan apabila koefisien 
determinasi mendekatii 1 maka dapat di simpulkan bahwa variabel independen berpengaruh terhadap variabel dependen. Selain itu, koefisien determinasi $\left(R^{2}\right)$ dipergunakan untuk mengetahui presentase perubahan variabel bebas $(Y)$ yang disebabkan oleh variabel bebas $(X)$ (Sarjono, 2011:110).

\section{Uji Hipotesis}

\section{Uji † (Parsial)}

Uji ini dimaksudkan untuk mengetahui tingkat signifikansi pengaruh masing-masing variabel bebas terhadap variabel terikat dengan asumsi variabel bebas yang lain tidak tidak berubah (cateris paribus).Langkah-langkahnya adalah sebagai berikut:

1. Menentukan formulasi $\mathrm{H}_{0}$ dan $\mathrm{H}_{1}$

$\mathrm{H}_{0}$ : Variabel Value Added Capital Employed (VACA), Value Added Human Capital (VAHU), Structural Capital Value Added (STVA) secara parsial berpengaruh tidak signifikan terhadap Return On Asset (ROA) pada Bank Umum Syariah (BUS).

$\mathrm{Ha}_{\mathrm{a}}$ : Variabel Value Added Capital Employed (VACA), Value Added Human Capital (VAHU), Structural Capital Value Added (STVA) secara parsial berpengaruh signifikan terhadap Return On Asset (ROA) pada Bank Umum Syariah (BUS).

2.Menenetukan daerah penerimaan dengan menggunakan uji t. Jika signifikansi uji † lebih kecil atau $=0,05$ maka dapat di simpulkan bahwa variabel independen secara parsial berpengaruh signifikan terhadap variabel dependen, (menolak $\mathrm{H}_{0}$ dan $\mathrm{H}_{\mathrm{a}}$ ). Jika signifikansi uji $\dagger$ lebih besar dari 0,05 maka dapat disimpulkan bahwa variabel independen secara parsial berpengaruh tidak signifikan terhadap variabel dependen. (Sarjono, 2011:109).

\section{Uji F (Simultan)}

Digunakan untuk menguji signifikan pengaruh seluruh variabel bebas (independen) secara bersama-sama terhadap variabel terikat (dependen). Uji simultan dalam penelitian ini menggunakan hipotesis sebagai berikut:

$\mathrm{H}_{0}$ : Variabel Value Added Capital Employed (VACA), Value Added Human Capital (VAHU), Structural Capital Value Added (STVA) secara simultan berpengaruh tidak signifikan terhadap Return On Asset (ROA) pada Bank Umum Syariah (BUS).

$\mathrm{H}_{a}$ : Variabel Value Added Capital Employed (VACA), Value Added Human Capital (VAHU), Structural Capital Value Added (STVA) secara simultan berpengaruh signifikan terhadap Return On Asset (ROA) pada Bank Umum Syariah (BUS).

\section{HASIL DAN PEMBAHASAN}

\section{Analisis Regresi Data Panel}

Analisis data panel terlebih dahulu harus melakukan pem-bentukan model regresi data panel yang sesuai sebagai model estimasi.). Dalam menentukan estimasi model regresi data panel, dilakukan beberapa uji untuk memilih metode pendekatan estimasi yang sesuai. Langkah-langkah yang dilakukan dalam 
Muhanik, et al/Jurnal Ekonomi Syariah Teori dan Terapan Vol. 4 No. 1 Januari 2017: 1-13; PENGARUH INTELLECTUAL CAPITAL TERHADAP RETURN ON ASSET PADA BANK UMUM SYARIAH DI INDONESIA PERIODE Q1.2013 - Q4.2014

mendapatkan model yang yang tepat adalah dilakukan uji Chow Test dan dan uji Hausman Test.

Setelah dilakukan pengujian Chow Test maka diperoleh nilai Probabilitas (Cross-section F) sebesar 0,0712 lebih besar dari a $(0,05)$ sehingga $H_{1}$ ditolak, dan dapat disimpulkan bahwa Pooled Least Square/Common Effect Model (CEM) lebih tepat dibandingkan dengan Fixed Effect Model (FEM). Berdasarkan uji tersebut maka menggunakan metode common effect model (CEM) atau Pooled Least square sehingga tidak perlu dilakukan pengujian Hausman.

\section{Koefisien Determinasi $\left(R^{2}\right)$ dan Koefisien Korelasi R}

Koefisien determinasi $\left(R^{2}\right)$ pada intinya mengukur seberapa jauh kemampuan model dalam menerangkan variasi variabel independen (Ghozali, 2013:97). Semakin besar koefisien determinasi, semakin besar variasi variabel independennya mempengaruhi variabel dependen.

Berdasarkan tabel dapat diketahui bahwa nilai Adjusted $\mathrm{R}^{2}$ sebesar 0,596035. Hal ini menunjukkan bahwa variabel Value Added Capital Employed (VACA), Valve Added Human capital (VAHU), dan Structural Capital Value Added (STVA) dapat menjelaskan variabel ROA sebesar $59,60 \%$, sedangkan sisanya sebesar $40,397 \%$ dijelaskan oleh variabel-variabel lain diluar model atau diluar variabelvariabel yang diteliti.

Nilai R (koefisien korelasi) sebesar 0,609965 (60,99\%), Menurut Sugiono (1998) korelasi dikatakan sedang apabila $R$ (koefisien korelasi) bernilai antara 0,40,599 dan apabila bernilai antara 0,6 0,799 maka korelasi dikatakan kuat. Sehingga kesimpulan dari nilai $R$ adalah hubungan antara variabel bebas yang terdiri atas Value Added Capital Employed (VACA), Value Added Human capital (VAHU), Structural Capital Value Added (STVA) terhadap Return on Assets (ROA) adalah kuat.

\section{Uji Signifikansi Simultan (F Test)}

Berdasarkan tabel diketahui tingkat probabilitas (F-statistic) sebesar 0,000000 yang lebih kecil dari a $(0,05)$, sehingga $\mathrm{H}_{0}$ ditolak dan dapat disimpulkan bahwa secara simultan berpengaruh signifikan terhadap ROA. Hasil ini mendukung penelitian Chen et al. (2005) yang menunjukan bahwa apabila penggunaan dan pemanfaatan intellectual capital semakin baik maka dapat meningkatkan profitabilitas perusahaan, sehingga kinerja akan semakin baik. Oleh karena itu kemampuan perusahaan dalam menghasilkan laba dengan total aset yang dimiliki akan semakin meningkat apabila perusahaan dapat memaksimalkan kinerja intellectual capital. Sebagaimana firman Allah dalam Al-Qur'an surah Ar-Rahman ayat 33:

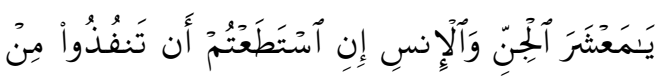

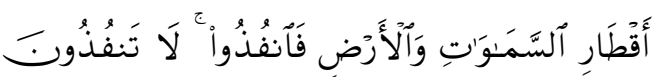

$$
\begin{aligned}
& \text { (إلَاَ بِسُلََْنَنِ }
\end{aligned}
$$

Ya másyaral-jinni wal-insi inistata tum an tanfużu min aqtaris-samawati walardi fanfużu, la tanfużuna illa bisultan 
Artinya: "Hai golongan jin dan manusia, jika kamu sanggup menembus (me-lintasi) penjuru langit dan bumi, maka lintasilah, kamu tidak dapat menembusnya melainkan dengan kekuatan (dari Allah)."(Q.S.55:33, Departemen Agama RI, 2010:532)

Tafsir Al-Mishbah (2002:307) dalam volume 13, ayat diatas menjelaskan pentingnya ilmu pengetahuan bagi kehidupan umat manusia. Dengan ilmu pengetahuan, manusia dapat mengetahui benda-benda langit. Dengan ilmu pengetahuan, manusia dapat menjelajahi angkasa raya. Dengan ilmu pengetahuan, manusia mampu menembus sekat-sekat yang selama ini belum terkuak. Manusia diberi potensi oleh Allah SWT berupa akal maka ini harus terus diasah, diberdayakan dengan cara belajar dan berkarya. Dengan belajar, manusia bisa mendapatkan ilmu dan wawasan yang baru. Dengan ilmu, manusia dapat berkarya untuk kehidupan yang lebih baik. Dan ini juga dapat di realisasikan terhadap perusahaan apabila kinerja karyawan ditingkatkan maka return yang dihasilkan juga bisa lebih baik.

\section{Pengaruh Value Added Capital Employed (VACA) terhadap Return on Asset (ROA)}

Pengaruh Value Added Capital Employed (VACA) terhadap Return on Asset ( $R O A$ ) dalam penelitian ini dapat dilihat dari uji parsial (uji t) dimana hasil dari uji $\dagger$ menunjukan bahwa tingkat signifikan VACA sebesar 0,3352 yang berarti lebih besar dari kriteria tingkat signifikan 0,05 sehingga dapat membuktikan bahwa VACA tidak berpengaruh signifikan terhadap Return on Asset (ROA). Hasil ini membuktikan bahwa Value Added Capital Employed pada bank umum syariah tidak memberikan kontribusi dalam peningkatan Return on Asset (ROA).

Berikut pandangan Islam dalam membina hubungan baik dengan orang lain yang dijelaskan dalam al-qur'an surah Al-Mujadilah ayat 11:

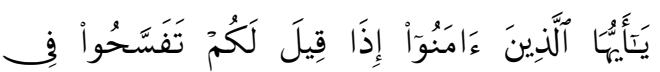

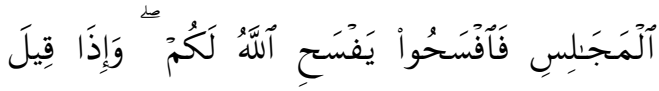

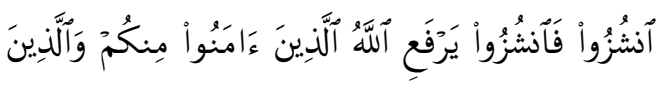

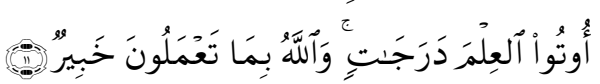

Yā ayyuhallazîna āmanu iżō qila lakum tafassahu fil majailisi fafsahu yafsahillahu lakum, wa iza- qilansyuzu fansyuzu yarfa illahullazina àmanu mingkum walazina ütul- ilma darajād, wallahu bima- tamaluna khabir

Artinya: "Hai orang-orang beriman apabila kamu dikatakan kepadamu: "Berlapang-lapanglah dalam majlis", Maka lapangkanlah niscaya Allah akan memberi kelapangan untukmu. dan apabila dikatakan: "Berdirilah kamu", Maka berdirilah, niscaya Allah akan meninggikan orang-orang yang beriman di antaramu dan orang-orang yang diberi ilmu pengetahuan beberapa derajat. dan Allah Maha mengetahui apa yang kamu kerjakan." (Q.S.58:1 1, Departemen Agama RI, 2010:543)

Tafsir Al-Misbah (2002:488) dalam volume 13 ayat diatas dijelaskan larangan berbisik yang merupakan salah satu tuntunan akhlak guna membina hubungan harmonis antara sesama. Ayat di atas merupakan tuntunan akhlak. Maka 
sesuai dengan penjelasan ayat diatas dalam membina hubungan baik antar relasi atau teman kerja itu dapat dilakukan agar dapat tercapai tujuan dari sebuah organisasi atau perusahaan.

\section{Pengaruh Value Added Human Capital (VAHU) terhadap Return On Asset (ROA)}

Pengaruh Value Added Human Capital (VAHU) terhadap Return on Asset (ROA) dalam penelitian ini dapat dilihat dari uji parsial (uji †) dimana hasil dari uji $\dagger$ menunjukan bahwa tingkat signifikan VAHU sebesar 0,0000 yang berarti lebih kecil dari kriteria tingkat signifikan 0,05 sehingga dapat membuktikan bahwa VAHU berpengaruh signifikan terhadap Return on Asset (ROA). Hasil ini membuktikan bahwa Value Added Human Capital pada bank umum syariah memberikan kontribusi dalam peningkatan Return on Asset (ROA).

Pengelolaan modal manusia dapat dilaksanakan secara profesional, maka diharapkan sumber daya manusia dapat bekerja secara efisien, efektif, dan produktif. Pengelolaan modal manusia secara profesional ini harus dimulai sejak perekrutan, seleksi, pengklasifikasian, penempatan sesuai dengan kemampuan, pelatihan dan pengembangan karirnya. Sebagaimana firman Allah SWT dalam surah Al-Imran [3]:104:

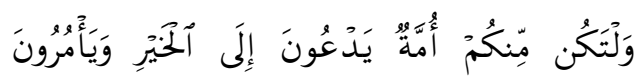

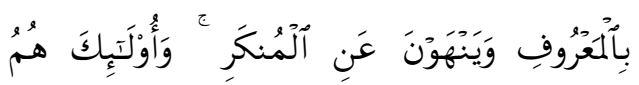

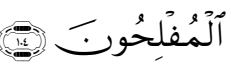

Waltakum mingkum ummatuy yaduna ilal khairi wa ya muruna bilmarufi wa yan-hauna anilmungkar, wa ula ika humul-muflihun Artinya: "Dan hendaklah diantara kamu ada segolongan orang yang menyeru kepada kebajikan, menyuruh (berbuat) yang makruf, dan mencegah dari yang mungkar. Dan merekah orang-orang yang beruntung."(Q.S.3:104, Departemen Agama Rl, 2010:50)

Tafsir al Mishbah (2002:208) ayat di atas menjelaskan bahwa Allah memerintahkan orang yang beriman untuk menempuh jalan yang berbeda yaitu menempuh jalan luas dan lurus serta mengajak orang lain menempuh jalan kebaikan dan makruf. Tidak dapat disangkal bahwa pegetahuan yang dimiliki seseorang, bahkan kem-ampuannya mengamalkan sesuatu akan berkurang, bahkan terlupakan dan hilang, jika tidak ada yang mengingatkannya atau tidak di ulangi mengerjakanya. Disisi lain, pengetahuan dan pengalaman saling berkaitan erat, pengetahuan mendorong kepada pengalaman dan meningkatkan kualitas amal sedang pengalaman yang terlihat dalam kenyataan hidup merupakan guru yang mengajar individu dan masyarakat sehingga mereka belajar mengamalkannya. Maka manusia dan masyarakat perlu selalu di ingatkan dan diberi ke-teladanan.

\section{Pengaruh Structural Capital Value Added} (STVA) terhadap Return on Asset (ROA)

Pengaruh Structural Capital Value Added (STVA) terhadap Return on Asset (ROA) dimana hasil dari uji $\dagger$ menunjukan bahwa tingkat signifikan Structural Capital Value Added (STVA) sebesar 0,5827 yang berarti lebih besar dari kriteria tingkat 
signifikan $\quad 0,05$ sehingga dapat membuktikan bahwa Structural Capital Value Added (STVA) tidak berpengaruh signifikan terhadap Return on Asset (ROA). Hasil ini membuktikan bahwa Structural Capital Value Added (STVA) pada bank umum syariah tidak memberikan kontribusi dalam peningkatan Return on Asset (ROA).

Perusahaan apabila memiliki modal struktural (planning, organizing, strategi, prosedur, sistem dan aset lainya) tetapi tidak dimaksimalkan maka tidak akan meningkatkan laba sebuah perusahaan. Sebagaimana firman allah dalam Al-Quran surat Yusuf ayat 47-49:

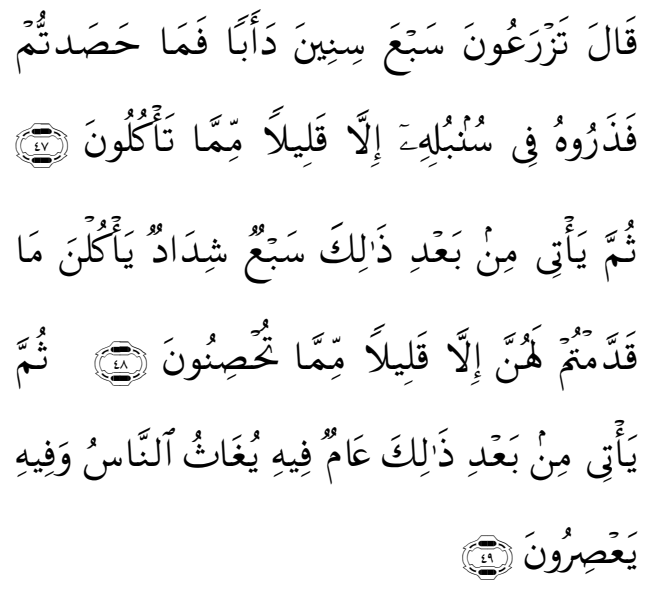

Qala tazra'una sab'a sinina ddaba, fa ma hasattum fa żaruhu fi sumbulihi illa qalilam mimma takulun. summa ya 'i mim badi żđlika sab'un syidaduy ya kulna ma qaddamtum lahunna illa qalilam mimma tuhsinun. summa yati mim badi żđlika 'amun fihi yugaśunnasu wa fihi ya'sirun.

Artinya: Yusuf berkata: "Supaya kamu (raja) bertanam tujuh tahun lamanya sebagaimana biasa, maka apa yang kamu tuai hendaklah kamu biarkan bulirnya kecuali sedikit untuk kamu makan. Kemudian akan datang tujuh tahun yang amat sulit, yang menghabiskan apa yang kamu simpan untuk menghadapinya (tahun sulit), kecuali sedikit dari (bibit gandum) yang kamu simpan. Kemudian setelah itu akan datang tahun yang padanya manusia diberi hujan (dengan cukup) dan dimasa itu mereka memeras anggur."(Q.S.10:47-49, Departemen Agama Rl, 2010:214)

Tafsir Al-Mishbah (2002:111) dalam volume 6, ayat diatas dijelaskan bahwa Yusuf menyuruh pada seorang raja untuk mempersiapkan atau mengatur cara untuk menghadapi masa-masa sulit yang cukup panjang, dan ini adalah salah satu fungsi dari manajemen itu sendiri yaitu perencanaan (planning), merencanakan agar raja segera bercocok tanam untuk menghadapi masa-masa sulit selama 7 tahun kedepan. Agar rakyatnya tidak ada yang kelaparan pada musim kemarau nanti. Dan juga pengaturan (organizing) dalam hal persediaan makanan, tidak semua hasil tanam yang mereka tanam dimakan pada saat tujuh tahun awal, tapi juga mempersiapkan makanan untuk tujuh tahun berikutnya (masa kemarau). Dan itu berlaku dalam sebuah perusahaan apabila modal struktural (planning, organizing, strategi, prosedur, sistem dan aset lainya) apabila tidak dimaksimalkan maka tidak akan meningkatkan laba sebuah perusahaan.

\section{SIMPULAN}

Berdasarkan hasil penelitian dan pembahasan yang telah dilakukan mengenai hubungan Value Added Capital Employed (VACA), Value Added Human capital (VAHU), dan Structural Capital Value Added (STVA) terhadap 
Return on Asset (ROA) maka simpulan yang dapat diambil adalah :

a. Variabel VACA, VAHU, STVA berpengaruh signifikan secara simultan terhadap Return on Assets (ROA) Bank Umum Syariah

b. Variabel VACA tidak ber-pengaruh signsifikan secara parsial terhadap Return on Assets (ROA) Bank Umum Syariah

c. Value $\mathrm{VAHU}$ berpengaruh signifikan secara parsial terhadap Return on Assets (ROA) Bank Umum Syariah

d. Structural Capital Value Added (STVA) tidak berpengaruh sig-nifikan secara parsial terhadap Return on Assets (ROA) Bank Umum Syariah pada.

\section{DAFTAR PUSTAKA}

Ajija Shochrul R, Dyah W. Sari, Rahmad H. Setianto, Martha R. Primanti. 2011. Cara Cerdas Menguasai Eviews. Jakarta:Salemba Empat

Astuti, P.D. dan A. Sabeni. 2004. "Hubungan Intellectual Capital dan Business Performance." Jurnal MAKSI. Vol 5, 34-58

Departemen agama RI. 2010. Mushaf AlAzhar: Al-Qur'an dan Terjemah. Bandung: Jabal Roudhotul Jannah

Ghazali, imam dan Dwi Ratmono. 2013. Aplikasi Analisis Multivariate dan Ekonometrika. Semarang: Badan penerbit Universitas Diponegoro

Ikatan Akuntan Indonesia. 2007. Standar Akuntansi Keuangan. Jakarta: Salemba Empat

Kasmir. 2014. Analisis Laporan Keuangan. Jakarta : Raja Grafindo Persada

Kuncoro, M \& Suhardjono. 2002. Manajemen Perbankan :Teori dan Aplikasi. Yogyakarta: BPFE

Kuryanto, Beny dan muhammad Syafrudin. 2008. "Pengaruh Modal
Intelektual Terhadap Kinerja Perusahaan."Fakultas Ekonomi Jurusan Akuntansi, Universitas Diponegoro

Purnomosidhi, Bambang. 2006. "Praktik Pengungkapan Modal Intelektual Pada Erusahaan Publik Di BEJ." Jurnal riset akuntansi Indonesia. Vol 4, No. 2 202214

Sangkala. 2006. Intellectual Capital Management: Strategi Baru Membangun Daya Saing Perusahaan. Jakarta: Yapensi

Sangkala. 2006. Knowledge Management. Jakarta: PT.Raja Grafindo Persada

Sarjono, Haryadi dan julianita, winda. 2011 . SPSS VS LISREL: Sebuah pengantar. Aplikatif Untuk Riset. Jakarta: Selemba Empat

Satiti, Ajeng dan Nur Fadjiih Asyik. 2013. Pengaruh Intellectual Capital terhadap Kinerja keuangan Perusahaan Asuransi. Jurnal akuntansi Vol.7

Shihab, M. Quraisy. 2002. Tafsir Al-Mishbah: Pesan, Kesab, dan Keserasian, AlQur'an. Vol 2-15. Jakarta: Lentera Hati

Siregar. 2014. Keterbatasan SDM Ber-latar Belakang Pendidikan Ekonomi Syariah. http://news.universitasazzahra.ac.id/ket erbatasan-sdm-ber-latar-belakang pendidikan-ekonomi-syariah/ suara karya (Online) (diakses pada 19 oktober 2015)

Sugiono. 1998. Metode Penelitian Bisnis. Cetakan ketiga. Bandung: Alfabeta

Sugiyono. 2011. Metode Penelitian Kuantitatif, Kualitatif dan R\&D. Edisi Keduabelas. Bandung: Alfabeta

Ulum, Ihyaul. 2008a. "Pengaruh Intellectual Capital Terhadap Kinerja Kevangan Perusahaan Perbankan Di Indonesia." Call for Paper simposium nasional akuntansi XI. Ikatan Akuntan Indonesia. Pontianak

2009. Intellectual Cpital Konsep dan Kajian Empiris. Yogyakarta: Graha IImu

2013. "IB-VAIC: Model Pengukuran Kinerja Intellectual Capital Perbankan Syariah di Indonesia". Jurnal inferensi (terakreditasi), volume 7, no 1 , hlm 183-204. ISSN: 1978 